\title{
Ekonomiczne i polityczne współzależności i sprzeczności koncentracji władzy w kapitalizmie (w kręgu interpretacji myśli Marksa)
}

\section{The Economic and Political Interdependencies and Contradictions of the Concentration of Power in Capitalism (in the Circle of Interpretations of Marx's Thoughts)}

Stowa kluczowe: kapitalizm, koncentracja, monopolizacja, państwo, marksizm

Keywords: capitalism, concentration, monopolization, state, Marxism

Abstrakt: Wartykule zastaja poddane analizie różne przejawy koncentracji władzy charakterystyczne dla tendencji istniejących w ramach systemu kapitalistycznego. Przedstawione zostają współzależności i sprzeczności związanych z tym procesów $w$ wymiarach bezpośrednio ekonomicznym i politycznym. Wodniesieniu do problemu zbadana zostaje adekwatność rozumienia tendencji rozwojowych kapitalizmu w ujęciu Marksa oraz części późniejszych myślicielek i myślicieli mieszczących się w różnych tradycjach ideowych odwotujących się do marksizmu.

Abstract: The article presents various manifestations of concentration of power characteristic of tendencies existing within the capitalist system. The interdependencies and contradictions of related processes are presented in the directly economic and political dimensions. In relation to the problem, the adequacy of understanding the developmental tendencies of capitalism in Marx's approach and some of the later thinkers rooted in various ideological traditions referring to Marxism is examined.

* ORCID ID: https://orcid.org/0000-0002-6947-5165, doktor habilitowany, Wydział Nauk Politycznych i Studiów Międzynarodowych, Uniwersytet Warszawski. Zainteresowania badawcze obejmują kwestie idei politycznych, ruchów społecznych oraz mechanizmy działania państwa i imperializmu kapitalistycznego. 
Zmarła w 2017 r. kanadyjska myślicielka Ellen Meiksins Wood, jedna z twórczyń szkoły tzw. „marksizmu politycznego”, zauważyła, że kapitalizm tym różni sięod innych sposobów organizacji społeczeństw klasowych, że wymiar polityczny zostaje w nim odseparowany od ekonomicznego. Innymi słowy, stosunki zależności ekonomicznej - a tym samym stosunki wyzysku - zostają oddzielone od bezpośredniego związku z państwem, jawiąc się jako strefa neutralna, poddana obiektywnym, zdepersonalizowanym prawom. Wood szła w swoich rozważaniach za daleko. Dominację niezależnego od państwa „imperatywu rynku” i związanego z tym imperatywem przymusu ekonomicznego postrzegała jako istotę kapitalizmu, choć przecież historia jego rzeczywistej postaci wskazuje na szereg możliwości relacji władzy ekonomicznej i politycznej, włącznie ze znaczącym pokrywaniem się obu tych postaci władztwa. Paradoksalnie Wood zbliżała się tym samym do utożsamiania tego systemu z charakterystycznym dla myśli liberalnej ideałem wolnorynkowym. Do tego stopnia, że negowała kapitalistyczny charakter podbojów kolonialnych przełomu XIX i XX wieku, jako że wciąż realizowane były poprzez rozpościeranie formalnej władzy państwowej. Za pierwsze w pełni kapitalistyczne mocarstwo uznała dopiero Stany Zjednoczone po 1945 r., prowadzące podbój metodami ekonomicznymi bez formalnej aneksji, z państwem stojącym na (zbrojnej) straży tej nowej postaci imperializmu¹.

Niemniej jednak wskazanie na separację motywu ekonomicznego i politycznego w kapitalizmie - gdy potraktujemy go jako możliwość, a nie konieczność - jest istotnym punktem wyjścia dla rozważań o istocie koncentracji władzy w ramach społeczeństwa kapitalistycznego. To w jego ramach nie tylko po raz pierwszy w takiej skali potęga władzy ekonomicznej - dotycząca samego posiadania i kontroli środków produkcji bogactwa społecznego - nie musi przekładać się bezpośrednio na władztwo polityczne, ale i ekspansja ekonomiczna może mieć miejsce niezależnie od ekspansji politycznej. Znów, dodajmy, że w bezpośrednim wymiarze.

Na wstępie należy jednak postawić pytanie, co w ogóle kryje się pod pojęciem „kapitalizm”? Odpowiedzi oczywiście może pojawić się wiele, także w zależności od ideowych dyspozycji osoby odpowiadającej. Kluczową kwestiąjest jednak dotarcie do istoty kolosalnej zmiany społecznej w skali świata, z którą bez wątpienia mieliśmy do czynienia w szczególności w czasie ostatnich dwóch wieków. Dla uchwycenia sprzecznej

${ }^{1}$ E.M. Wood, Empire of Capital, London, New York 2005, s. ix-xiii, 124-130. 
dynamiki ( $w$ tym sensie - dialektyki ${ }^{2}$ ) rozwoju w tym okresie - produkującego mikroprocesory, smartfony i misje na Marsa, jak i głód, katastrofę ekologiczną i Holokaust - najbardziej adekwatna wydaje się odpowiedź Marksa. Według niej kapitalizm to system stosunków społecznych ukształtowany przez sposób produkcji oparty na konkurencyjnej akumulacji kapitału. Kapitał to z kolei pozornie „samopomnażająca się” wartość, istniejąca w specyficznych stosunkach społecznych w produkcji opartych z jednej strony na konkurencji, prowadzącej do konieczności tego bezgranicznego pomnażania, a z drugiej na wyzysku pracy najemnej, który to pomnażanie umożliwia. W skrócie, jak trafnie ujął to przedstawiciel jednej ze „szkół” zainspirowanych marksizmem, teoretyk „systemówświatów" Immanuel Wallerstein, kapitalizm to system oparty na pędzie ku niekończącej się akumulacji kapitału ${ }^{3}$.

Ta istota działania kapitalizmu prowadzi to nieporównywalnej z wszystkimi innymi sposobami organizacji społeczeństwa dynamiki ekspansji, która wciągnęła w kapitalistyczne ramy cały świat, prowadząc po raz pierwszy w historii do prawdziwie globalnej gospodarki opartej na sieciach bezpośredniej współzależności. Geograficznemu rozwojowi kapitalizmu - nazwijmy go ekstensywnym - towarzyszy jednak nieustanny rozwój intensywny, ciągła przemiana jego postaci w ramach siebie samego. Kapitalizm jest więc systemem historycznym nie tylko w tym sensie, że pojawia się w określonym momencie ludzkiej historii, ale ma też własną historię rozwoju naznaczoną koniecznością wyrastającą z samej jego istoty. W pierwszym tomie Kapitału K. Marks wskazał na procesy koncentracji i centralizacji kapitału. Koncentracja to skutek powiększania „masy bogactwa funkcjonującego jako kapitał” tożsama z samym procesu akumulacji. Gdy raison d'être jest pomnażanie kapitału, skutkiem musi być istnienie coraz większych jego jednostek. Centralizacja jest z kolei łączeniem się kapitałów w celu skuteczniejszej konkurencji, przekształceniem w ten sposób mniejszych w większe i skuteczniejsze unicestwianie drobnych jego właścicieli przez wielkich. Rozwój kapitalizmu prowadzi więc do konkurencji coraz większych jednostek kapitału4. W „czystym” kapitalizmie, czyli społeczeństwie składającym się jedynie z kapitalistów i pracowników najemnych (branym w Kapitale jako model teoretyczny stopniowo umiejscawiany w rzeczywistości empirycznej), ideał „wolnego

\footnotetext{
${ }^{2} \mathrm{Na}$ temat dialektyki kapitalizmu zob. F. Ilkowski, Dialektyka imperializmu kapitalistycznego, «Studia Politologiczne» 2016, vol. 41.

${ }^{3}$ I. Wallerstein, Analiza systemów-światów. Wprowadzenie, Warszawa 2007, s. 42.

${ }^{4}$ K. Marks, Kapitat, t. 1, Warszawa 1951, s. 674-676.
} 
rynku" prowadzi więc do własnej negacji - dominacji coraz potężniejszych potęg kapitałowych.

\section{Koncentracja władzy ekonomicznej w realnym kapitalizmie}

Prognozy K. Marksa sformułowane w 1867 r. znajdują odzwierciedlenie $\mathrm{w}$ rzeczywistości realnego kapitalizmu. Porównując dane z Fortune 500, pięciuset największych korporacji w Stanach Zjednoczonych, w ciągu pół wieku 1955-2005 przychody dziesięciu największych firm wzrosły z 34,4215 mld do 1649,883 mld USD w porównaniu do realnego Produktu Krajowego Brutto, który wynosił 2,68 bln USD w 1955 r. i 14,913 bln USD w 2005 r. Innymi słowy przychody te wyniosły $1,28 \%$ w 1955 r. i 11,06\% w 2005 r. realnego PKB tej od ponad stulecia największej krajowej gospodarki świata kapitalistycznego. W 2018 r. było to 2,296557 bln w stosunku do realnego PKB w wysokości 18,566 bln USD, czyli udział wynoszący $12,36 \% 5$.

Według danych podawanych przez Thomasa Pikettego i Gabriela Zucmana w 1917 r. dochód narodowy Stanów Zjednoczonych, mierzony w wartościach bieżących, wynosił 49,3 mld USD. W $1967 \mathrm{r}$. było to 750 mld USD. W 1917 r. suma aktywów pięćdziesięciu największych korporacji amerykańskich, podana przez magazyn Forbes, wynosiła 11,760 mld USD, czyli 24\% dochodu narodowego. W 1967 r. było to 288,1 mld USD, czyli 38\% dochodu narodowego. W 2017 r.suma aktywów to 10839,2 mld USD. Dane Pikettego i Zucmana nie obejmuja już tego okresu. Można jednak skorzystaćz obliczeń Banku Światowego odnoszących się do dochodu narodowego netto w USA, w latach 1970-2017, które są bardzo do nich zbliżone ${ }^{6}$. Na ich podstawie wynosiłon w $2017 \mathrm{r}$. 16,74 bln USD, co oznacza, że suma aktywów największych pięćdziesięciu korporacji wynosiła już 65\% dochodu narodowego netto USA7 ${ }^{7}$.

5 Fortune 500, A database of 50 years of FORTUNE's list of America's largest corporations, http://archive.fortune.com/magazines/fortune/fortune500_archive/full/1955 (3.02.2020); Fortune 500, http://fortune.com/fortune500/list (3.02.2020); K. Amadeo, US GDP by Year Compared to Recessions and Events, „the balance”, https://www.thebalance.com/us-gdp-by-year-3305543 (3.02.2020) (obliczenia własne).

6 W odniesieniu do 1970 r.: 930 mld USD według Pikettego i Zucmana i 937,5 mld USD według Banku Światowego; w odniesieniu do 2010 r.: 12822 mld USD według Pikettego i Zucmana i 12655 mld USD według BŚ.

7 T. Piketty, G. Zucman, PIKETTY-ZUCMAN WEALTH-INCOME DATA SET, Table US.2: National income and private wealth in the U.S., 1770-2010 (annual series), piketty.pse. 
Biorąc pod uwagę ogólną sumę przychodów pięciuset największych korporacji świata pod względem wielkości ich przychodów (lista Fortune Global 500), to wzrosła ona z 10784,5 mld USD w 1994 do 25469,1 mld USD w 2009 r. $^{8}$, czyli o 136,2\%. Globalne PKB wzrosło w tym samym czasie o 117,1\%. Ciekawa jest analiza danych lat 2005-2018, która mimo czasów kryzysu gospodarczego i poważnych wahań przychodów i zysków największych korporacji zasadniczo potwierdza ogólny trend. Suma przychodów dziesięciu największych korporacji z listy z 2005 r. wynosiła 2133,039 mld USD. W 2018 r. wynosiła ona 3070,359 mld USD, co stanowiło wzrost o 44\%. W przypadku pierwszej pięćdziesiątki jest to odpowiednio 5494,906 i 8960,871 mld USD (wzrost o 63\%). Ogólna suma przychodów pierwszej pięćsetki osiągnęła jednak w 2018 r. 30 bln USD wobec 16,7 bln w 2005 r.(Wzrost o 79,6\%), przy wzroście PKB w latach 2005-2017 o 70,4\%. Przy tym bariera wstępu do pierwszej pięćsetki wzrosła z 12,431 do 23,556 mld, czyli o $89,5 \%{ }^{9}$

Według portalu statystycznego Statista wartość rynkowa dziesięciu największych korporacji na świecie w 2018 r. wynosiła 5977,6 mld USD, a stu największych - 20548,7 mld USD ${ }^{10}$. Pokrywa się to z danymi PricewaterhouseCoopers, według których wartość rynkowa (marketcapitalisation) stu największych korporacji wynosiła pod koniec pierwszego kwartału 2018 r. 20035 mld USD. W tym samym okresie 2009 r.było to 8402 mld USD, ale 13530 mld USD w 2008 r. ${ }^{11}$ Globalny Produkt Kra-

ens.fr/files/capitalisback/USA.xlsx (3.02.2020); J. Kauflin, America's Top 50 Companies 1917-2017, «Forbes» 19.09.2017, https://www.forbes.com/sites/jeffkauflin/2017/09/19/ americas-top-50-companies-1917-2017/\#6bf324be1629 (3.02.2020); The World Bank. Data, Adjusted net national income (current US\$), https://data.worldbank.org/indicator/ NY.ADJ.NNTY.CD?locations=US (3.02.2020).

8 S. Sledge, Dynamic competition: a look at firms in the Fortune Global500, "Competitiveness Review» 2011, nr 21 (5), s. 428-440, doi: 10.1108/10595421111171939. Autorka pisze o milionach, a nie miliardach USD, co wydaje się oczywistą pomyłką.

${ }^{9}$ Obliczenia własne na podstawie: Fortune Global 500. Full list, 2018, http://fortune.com/ global500/list (3.02.2020); CNN Money, Fortune Global500. Full list, 2005, https:// money.cnn.com/magazines/fortune/global500/2005/index.html (3.02.2020); A. Lustgarten, Fortune Global500, CNN Money, 2.08.2006, https://money.cnn.com/magazines/ fortune/fortune_archive/2006/07/24/8381693/index.htm (3.02.2020).

10 Statista, The 100 largest companies in the world by market value in 2018 (in billion U.S. dollars), https://www.statista.com/statistics/263264/top-companies-in-the-world-by-marketvalue (3.02.2020) (obliczenia własne).

11 Pwc, Global Top 100 companies by market capitalization, An IPO Center publication, June 2013, https://www.pwc.com/gx/en/audit-services/capital-market/publications/assets/ document/pwc-top-100.pdf (3.02.2020); 31 March 2018 update, https://www.pwc.com/ gx/en/audit-services/assets/pdf/global-top-100-companies-2018-report.pdf (3.02.2020). 
jowy Brutto liczony w cenach bieżących wynosił, według danych Banku Światowego, 63587 bln USD w 2008 r., 60286 bln USD w 2009 r.i 80935 w 2017 r.12Stosunek wartości rynkowej stu największych światowych korporacji do światowego PKB wynosił więc 0,00021 w 2008 r., 0,00014 w 2009 r., ale już 0,0025 w latach 2017/18.

Niezależnie więc od wahań, trend historyczny wydaje sięjasny - coraz większe jednostki kapitału mają coraz istotniejszy udział w gospodarce kapitalistycznej jako całości. Innymi słowy, coraz większy jest wpływ na gospodarkęświatową kolosów kapitałowych. Dodajmy, że ta koncentracja władzy ekonomicznej może wiązać się z ekstremalną koncentracją bogactwa w skali globalnej, w rękach bardzo drobnej mniejszości ludzkości, co pokazuje teraźniejszość „realnego kapitalizmu”. Według raportu organizacji Oxfam Intermational ze stycznia 2019 r., w 2018 r. grupa 26 najbogatszych osób posiada bogactwo równe temu, które posiada biedniejsza połowa ludności świata (3,8 mld osób) ${ }^{13}$.

Należy jednak podkreślić, że rosnąca koncentracja władzy ekonomicznej w rękach coraz potężniejszych jednostek kapitału nie musi oznaczać ich prostej wszechwładzy, osiągnięcia pozycji gwarantującej pozostanie na szczycie kapitalistycznej piramidy gospodarczej. Obserwując listę 50. największych korporacji amerykańskich w latach 1917-2017 widzimy istotną fluktuację widniejących na niej spółek - która dotyczy także ostatnich dekad. Spośród sześciu największych korporacji w USA, w 2017 r., żadna nie widniała na tej liście pół wieku wcześniej, a pięć $\mathrm{z}$ nich nawet wtedy nie istniało (Apple, Alphabet, Microsoft, Amazon, Facebook). Tylko dwie spółki obecne na liście w 1917 r. utrzymały się na niej pod własnymi nazwami sto lat później (American Telephon\&Telegraph i General Electric). Bez wątpienia wskazuje to na sytuację daleką od wizji monopolistycznej stagnacji, w której kapitalistyczne molochy

12 The World Bank. Data, GDP (current US\$), https://data.worldbank.org/indicator/ NY.GDP.MKTP.CD (3.02.2020).

13 Oxfam International, 5 shocking facts about extreme global inequality and how to even it up, https://www.oxfam.org/en/even-it/5-shocking-facts-about-extreme-global-inequalityand-how-even-it-davos (3.02.2020). Należy przy tym podkreślić, że realny kapitalizm niekoniecznie oznaczać musi potęgowanie tak krańcowych nierówności. Takie państwa, jak Stany Zjednoczone, Wielka Brytania i Francja, doświadczyły od 1913 r. do końca lat siedemdziesiątych (w przypadku USA) i początku lat osiemdziesiątych XX wieku (w przypadku Wielkiej Brytanii i Francji) istotnego spadku bogactwa najbogatszego $1 \%$ obywateli w stosunku do indywidualnego bogactwa całości. Od tego czas trend jest jednak odwrotny (najwyraźniej w USA). Patrz: F.Alvaredo, L. Chancel, T.Piketty, E. Saez, G. Zucman, World Inequality Report 2018. Executive Summary, https://wir2018. wid.world/executive-summary.html (3.02.2020). 
nie podlegają już presji konkurencji i dzięki swojemu panowaniu gospodarczemu stają się prostymi „odcinaczami kuponów”. Samo pojawianie się nowych obszarów akumulacji kapitału wskazuje na wciąż istniejącą dynamikę systemu - nawet jeśli dynamika ta przejawia się także poprzez powielanie także na nowych obszarach dobrze znanych procesów centralizacji i koncentracji kapitału. Jednocześnie jednak podkreślićnależy nie tylko zmiany na liście gigantów, związane z dominacją nowych gałęzi gospodarczych, ale i ich stabilność w odniesieniu do gałęzi już istniejących i wciąż istotnych. Najwyraźniej widać to na rynku naftowym, gdzie cztery korporacje obecne wśród gigantów w 1917 r. wciąż znakomicie sobie radzą, tyle że pod innymi nazwami, zajmując sto lat później ósme (Exxon Mobil) i siedemnaste (Chevron) miejsce na liście. Generalnie spośród 50 największych korporacji amerykańskich w 1967 r, jeśli weźmiemy pod uwagę ich nowe wcielenie w wyniku zmian nazw i fuzji, na tej samej liście w 2017 r. znalazło się aż $31^{14}$.

\section{Trusty państwowokapitalistyczne}

Kwestia koncentracji i centralizacji kapitału i związanej z tym oligarchizacji gospodarki kapitalistycznej prowadziła istotną cześć kontynuatorów myśli Marksa do ujęcia problemu relacji władzy ekonomicznej i politycznej w kapitalizmie w sposób zupełnie inny niż czyniła to Wood. Wskazywali nie na odrębność, ale tendencję ku jednoczeniu się coraz potężniejszych kapitałów indywidualnych i państwa kapitalistycznego. Tendencję tę opisywał już Fryderyk Engels, określając nowoczesne państwo mianem „idealnego kapitalisty zbiorowego”15. W 1910 r. zagadnieniem tym zajął się austriacko-niemiecki socjaldemokrata Rudolf Hilferding. Jego praca Kapitał finansowy to z pewnością najbardziej wpływowa pozycja w nurcie marksistowskiej krytyki ekonomii politycznej przełomu XIX i XX wieku, z wpływem przekraczającym nawet publikację przez Engelsa, na podstawie notatek Marksa, III tomu Kapitału szesnaście lat wcześniej. Zasadnicza teza Hilferdinga mówiła o pełnej integracji kapitału bankowego i przemysłowego (pod dyktando tego pierwszego) w skartelizowanej gospodarce i bezpośrednim wpływie tak rozumianego fenomenu kapitału finansowego na politykę państw kapitalistycznych.

${ }^{14}$ J. Kauflin, America's Top 50 Companies...

${ }^{15}$ F. Engels, Anty-During. Przewrót w nauce dokonany przez pana Eugeniusza Duringa, [w:] K. Marks, F. Engels, Dzieła, t. 20, Warszawa 1972, s. 311. 
Ostatecznie doprowadziło to go do przekonania o przejściu do wolnej od kryzysów i wstrząsów gospodarczych fazy „kapitalizmu zorganizowanego" z możliwością jego demokratyzacji poprzez przejęcie kontroli nad władzą państwową - i dwukrotnego sprawowania stanowiska ministra finansów w czasach Republiki Weimarskiej z ramienia socjaldemokracji16. Jednak Hilferding wywarł także wpływ na marksistów wyciągających w tym czasie zupełnie inne wnioski praktyczne, mianowicie rosyjskich bolszewików w osobach Włodzimierza Lenina i Nikołaja Bucharina, w obu przypadkach dokonujących rekonstrukcji podejścia do problemu relacji kapitału, państwa i imperializmu w kontekście hekatomby I wojny światowej. Bardziej znana praca Lenina z 1916 r. na temat imperializmu bez wątpienia wywarła znacznie większy wpływ polityczny, ale z punktu widzenia tematu szczególnie interesująca wydaje się powstała rok wcześniej książka Bucharina Imperializm i gospodarka światowa ${ }^{17}$. Bucharin formułuje w niej pojęcie „trustów państwowokapitalistycznych” jako bytów powstałych w wyniku oddziaływania dwóch sprzecznych tendencji: ku umiędzynarodowieniu gospodarki i jej nacjonalizacji. Wskutek tego, jak argumentował, konkurencja wewnątrz każdego z państw zostaje przezwyciężona i przeniesiona na poziom międzynarodowy. Przy czym trusty państwowokapitalistyczne rywalizują nie tylko gospodarczo, ale i militarnie.

Nietrudno wskazać na jednostronności propozycji Bucharina. Mając przed oczami ściśle regulowane przez państwo gospodarki wojenne, upatrywał on w nich ostatecznej postaci kapitalizmu w skończonej formie pełnej tożsamości państwa i kapitału. Jednak ujmowana jako możliwość, będąca wyrazem tendencji rozwoju kapitalistycznego, nie traci ona na atrakcyjności. Historia realnego kapitalizmu dostarcza szeregu przykładów tożsamości, lub sytuacji bliskiej tożsamości, państwa i kapitału nie tylko w czasach wojennych. Najbardziej uderzającymi przykładami są tu nazistowskie Niemcy i, jakkolwiek paradoksalnie to brzmi, stalinowska Rosja - paradoks, nad którym trzeba sięjeszcze będzie pochylić. Co więcej, z dzisiejszego punktu widzenia odpowiedźna kryzys gospodarczy i społeczny w postaci zamykania się gospodarek w protekcjonistycznych blokach z rosnącą ekonomiczną rola państwa nie wydaje się tylko historycznym wspomnieniem, a wizja możliwości jego powtórzenia ze spiralną dynamiką znacznie potężniejszych organizmów gospodarczych

${ }^{16}$ R. Hilferding, Kapitat finansowy: studium o najnowszym rozwoju kapitalizmu, Warszawa 1958. Więcej na temat poglądów Hilferdinga oraz ich recepcji wśród współczesnych mu teoretyków: F. Ilkowski, Teorie klalsyczne imperializmu kapitalistycznego. Zarys krytyczny, Toruń 2015, s. 162-184, 254-320.

17 N. Bucharin, Imperializm i gospodarka światowa, Warszawa 1934. 
nie wydaje tak odległa, jak przed 2007 r. Jednak najcenniejsze w teorii Bucharina wydaje się dostrzeżenie dialektyki rozwoju kapitalistycznego łączącego rolę państwa kapitalistycznego i gospodarki światowej. Podobnie jak w przypadku spostrzeżeń Wood, w istotnej mierze przeciwstawnych Bucharinowi, uwolnienie ich od jednostronności pozwala na odkrycie faktycznie cennych elementów. W istocie dynamika kapitalizmu nacechowana jest zarówno odróżnialnością motywów ekonomicznego i politycznego, jak i tendencją do ich integracji.

\section{Monopolizacja i ideologia w państwie kapitalistycznym}

Państwo kapitalistyczne samo w sobie jest wyrazem monopolizacji władzy na różnych obszarach. Zgodnie ze znaną definicją Maxa Webera państwo oznacza „prawo monopolu na wywieranie prawomocnej przemocy fizycznej" w obrębie określonego terytorium ${ }^{18}$. Historycznie monopol ten niekoniecznie musiał istnieć w sensie ścisłym, a bardziej poprzez legitymizację tego, co jest, a co nie jest, prawomocnym użyciem siły. Niemniej jednak każde państwo ostatecznie opiera się na możliwości jej użycia. Wskazówka Webera, politycznie oscylującego między demokratycznym liberalizmem a niemieckim nacjonalizmem, jest tu zresztą bliska poglądowi rewolucyjnego socjalisty Fryderyka Engelsa, piszącego o władzy publicznej jako składającej się z „uzbrojonych ludzi, ale także z takich dodatków rzeczowych, jak więzienia i wszelkiego rodzaju instytucje przymusu" jako jednej z kluczowych cech państwa. Tyle, że w tym drugim przypadku, jasno łączonego z koniecznością związaną z istnieniem społeczeństwa klasowego, opartego na wyzysku ${ }^{19}$.

Na tle tej uniwersalnej cechy państw, państwo kapitalistyczne wyróżnia się własną specyfiką. Dotyczy ona nie tylko bardziej bezpośredniej monopolizacji prawomocnej przemocy w porównaniu z szeregiem postaci państw przedkapitalistycznych, mniej wszechogarniających pod tym względem, pozostawiających więcej poza bezpośrednią kontrolą władzy centralnej. Przede wszystkim jednak państwo kapitalistyczne nacechowane jest znacznie bardziej subtelną, ale jednocześnie systematyczną i jednolitą monopolizacją ideologii, rozumianej w tym kontekście jako

18 M. Weber, Polityka jako zawód i powołanie, [w:] Polityka jako zawód i powołanie, Kra- kówWarszawa 1998, s. 56.

${ }^{19}$ F. Engels, Pochodzenie rodziny, własności prywatnej i państwa, [w:] K. Marks, F. Engels, Dzieła, t. 21, Warszawa 1969, s. 187. 
system idei tłumaczących rzeczywistośćz punktu widzenia klasy panującej i tym samym legitymizujących to panowanie. Wynika to z zupełnie innej koncepcji obywatelstwa i suwerenności w porównaniu z przedkapitalistycznymi społeczeństwami klasowymi. Ideałowi „,wolnego rynku”, w którym każdy może uczestniczyć na równych zasadach, towarzyszy merytokratyczna wizja społeczeństwa, w którym każda osoba otrzymuje tyle, na ile zasłużyła swoją pracą i zdolnościami. Pod względem formalnym kapitalizm jest społeczeństwem bezklasowym, w którym każda osoba jest równym wobec prawa obywatelem (a od stosunkowo niedługiego czasu zwykle także równą wobec prawa obywatelką), a ich ogół tworzy lud-naród stanowiący suwerenną władzę. Ideologia społeczeństw formalnie zróżnicowanych na szereg stanów o oddzielnych prawach (czy bezprawiach), przy suwerenności przypisywanej albo bezpośrednio władcy, albo niewielkiej grupie ludności - przy tym społeczeństw charakteryzujących się znacznie mniejszą dynamiką w porównaniu z tym opartym o niekończącą się akumulację kapitału - nie wymagała szczególnego zniuansowania, ostatecznie opierając się na różnych postaciach sankcji religijnej. Kapitalizm przyniósł pod tym względem prawdziwy przewrót.

Kluczowym elementem ideologii społeczeństwa kapitalistycznego jest patriotyzm, czy też nacjonalizm w szerokim sensie tego słowa, bliskim jego rozumieniu w świecie anglosaskim, tzn. wykraczającym poza wąskie ujęcie jako postaci prawicowego ekstremizmu i odnoszącym się do samego poczucia przynależności do określonej wspólnoty narodowej. Patriotyzm to $w$ istocie najgłębiej zakorzeniona świecka religia kapitalizmu, z własnymi świętymi symbolami i mitologią. Obserwując jej powszechność niewiarygodne wydaje się, jak młody jest to fenomen, włączając w to flagi, godła i hymny narodowe. Mieszczący sięw tradycji weberowskiej Ernest Gellner wskazywał na związek pojawienia się nacjonalizmu z potrzebami rodzącego się społeczeństwa przemysłowego ${ }^{20}$. Z kolei wyrastający z nurtu Nowej Lewicy Benedict Anderson upatrywał przyczyn rozwoju świadomości narodowej jako specyficznej „wspólnoty wyobrażonej" w procesie kruszenia się politycznej roli wielkich religii, upadku monarchii dynastycznych i pojawienia się linearnej koncepcji czasu $^{21}$. Wszystko to istotne wskazówki pomagające zrozumieć korzenie i ideologiczną funkcjonalność patriotyzmu, który wydaje się nieodłącznie

${ }^{20}$ E. Gellner, Narody i nacjonalizm, Warszawa 2009, s. 123-147.

21 B. Anderson, Wspólnoty wyobrażone: rozważania oźródłach i rozprzestrzenianiu się nacjonalizmu, Kraków 1997, s. 22-47. 
związany zarówno z obietnicą zawartą w pojęciu suwerenności równych wobec prawa obywateli, jak i niemożności realizacji tej obietnicy przy ich faktycznej nierówności w nowej postaci społeczeństwa opartego na wyzysku.

Z naszego punktu widzenia istotny jest w tym kontekście konkret ideologicznego monopolu państwa. Wprowadzenie powszechnego systemu edukacji miało niewątpliwie istotne znaczenie ekonomiczne, odpowiadając na potrzebę istnienia pracowników umiejących pisać, czytać i liczyć (jak i oczywiście bardziej - i coraz bardziej wraz z rozwojem kapitalizmu - wykwalifikowanej siły roboczej). Miało jednak także bardzo ważne znaczenie dla zakorzeniania ujednoliconej wykładni patriotyzmu. Obecnie kultywowanie lojalności wobec określonych symboli i zestawu mitów zaczyna się już na poziomie edukacji przedszkolnej (oczywiście w miejscach, gdzie takowa występuje) - ranga przypisywana wychowaniu patriotycznemu mierzyć się tu może jedynie z wychowaniem religijnym, przy czym państwowa sankcja współcześnie zawsze występuje w tym pierwszym, a nie zawsze $\mathrm{w}$ drugim przypadku. A przecież krzewienie patriotyzmu to nie tylko system edukacji, ale i szereg innych instytucji, niekoniecznie bezpośrednio związanych z państwem: od kościołów, po media czy sport. Gellner miał rację, choć nie pisał o kapitalizmie, ale o społeczeństwie przemysłowym, że oznacza ono rugowanie wcześniejszej kulturowej wielości istniejącej w granicach państwowych na rzecz jednego wzoru $^{22}$. Monopolizacja przekazu ideologicznego jest w tym kontekście bezprecedensowa. Przekonanie o przynależności do określonego narodu, pojęcie jego interesu i obowiązku poczucia lojalności wobec niego wydaje się, od niedawna z historycznego punktu widzenia, czymś „naturalnym”. Mogą mieć miejsce najbardziej zaciekłe spory o jego kształt przekładające się niespójności w mitologii. W każdej jednak formie z rodzajem teleologii, gdzie na końcu pojawia się naród ucieleśniony w konkretnym państwie i zawsze weryfikowane przez skuteczność realizacji tej drogi. Patriotyzm „otwarty” czy „zamknięty”, bardziej „nowoczesny” czy „tradycyjny", oparty o takie, a nie inne filary - spory te bez wątpienia nie są bez znaczenia, szczególnie dla poszczególnych grup w tych operacjach włączanych lub wyłączanych z rozmaicie konstruowanego „narodu”. Sam patriotyzm jest jednak poza sporem, a kwestionowanie go jest prawdziwym świętokradztwem świata ideologii kapitalizmu.

Należy przy tym wspomnieć, że to wszechogarnianie nie zawsze jest skuteczne. Każda ideologia podlega kontestacji i czymś, co można nazwać

22 E. Gellner, Narody i nacjonalizm..., s. 136-140. 
hybrydyzacją, czyli niezliczonym możliwościom mutacji polegających na łączeniu w powszechnej świadomości elementów ideologicznych i tych wynikających z ich kontestacji. Patriotyzm nie jest pod tym względem wyjątkiem. Dodajmy, że kontestacja może istniećtakże na jego własnym polu, tzn. patriotyzm dominujący i oficjalny w danym państwie może zderzyć się z rebelią konkurencyjnego patriotyzmu oferującego własną, alternatywną mitologię. Dynamika kapitalizmu, niesie także nierównomierność i złożoność jego rozwoju - by użyć pojęcia ukutego przez Lwa Trockiego ${ }^{23}$. Złożoność, w sensie kombinacji elementów archaicznych i technologicznie zaawansowanych wewnątrz państw kapitalistycznych. Nie bez racji współczesny marksista Alex Callinicos właśnie w istnieniu nierównomierności i złożoności rozwoju kapitalistycznego upatruje reprodukcji globalnego kapitalizmu w politycznej postaci systemu konkurujących państw kapitalistycznych ${ }^{24}$. W dodatku kapitalizm popada w okresowe kryzysy ekonomiczne, które mogą być i często są podstawą szerszych kryzysów politycznych i społecznych. W kontekście dialektyki rozwoju kapitalistycznego oznacza to stale powracającą pokusęoddzielenia się od obecnych państw i tworzenia nowych. Zwykle bazą ku temu są niezadowolone części klasy średniej, pociągające za sobą z jednej strony część klas wyższych - w wierze, że nowe państwo zapewni im skuteczniejszy „rozwój”, w sensie bardziej odpowiednich ram dla akumulacji kapitału - jak i klas podporządkowanych, upatrujących w nim nadzieję na awans społeczny i społeczną sprawiedliwość. Przy tym ruchy separatystyczne mogą mieć bardzo różne oblicze polityczne, wynikając z rzeczywistej lub urojonej opresji ze strony dominującego nacjonalizmu ucieleśnionego w polityce państwa. Jednak niezależnie od korzeni konkretnych nacjonalizmów i tego, czy są one jednocześnie ruchami narodowowyzwoleńczymi w sensie wyrastania z oporu wobec opresji, faktem jest, że realny kapitalizm - po okresie dążeń do łączenia jednoczenia gospodarczego i politycznego w jego wczesnej fazie rozwijającego się dopiero nacjonalizmu - w swoim historycznym rozwoju przyniósł znaczący wzrost liczby państw. Umiędzynarodowienie gospodarki i dominacja coraz większych jednostek kapitału idzie w parze ze zwielokrotnieniem liczby państw kapitalistycznych.

${ }^{23}$ L. Trocki, Historia rewolucji rosyjskiej, t. 1, Rewolucja lutowa, Warszawa 1932, https:// www.marxists.org/polski/trocki/1930/hrr/index.htm (3.02.2020). 


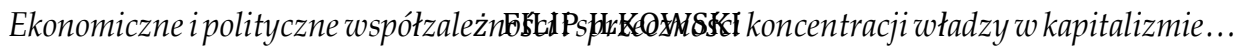

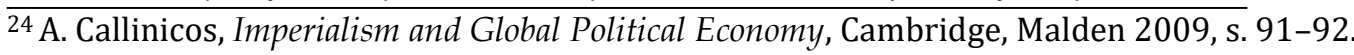




\section{Formy polityczne relacji państwa i kapitału}

Patriotyzm jest specyficznie istotną, ale oczywiście nie jedyną częścią tego świata. Kontrola państwowa nad nauczaniem oznacza także daleko idącą kontrolę nad przekazem ideologicznym na innych polach. Przy tym hegemonia ideologiczna - zgodnie z tym, co pisał w latach 30. XX wieku włoski marksista Antonio Gramsci - sprawowana jest przez klasę panującą nie tylko przez państwo, ale także szereg pozapaństwowych instytucji „społeczeństwa obywatelskiego”25. Dodajmy także, że podlega ona stałej kontestacji. Konkretne ramy sprawowania władzy ideologicznej określane są jednak przez charakter reżimu politycznego określonego państwa kapitalistycznego. Historia i współczesność realnego kapitalizmu obfituje tu w wielość form, za dwa krańcowe bieguny których można uznać demokrację parlamentarnąi faszyzm. W pewnej mierze odpowiadają one także modelom relacji państwa i kapitału przedstawionym przez Wood i Bucharina, z różnymi przejawami koncentracji i współzależności władzy ekonomicznej, politycznej i ideologicznej.

Wybór tych relacji nie jest dowolny. Dostępne alternatywy określane są z jednej strony przez stale trwające procesy koncentracji i centralizacji kapitału oraz tendencje kryzysowe wynikające z wiecznego powrotu spadającej stopy zysku, będące rodzajem podskórnej nici przewodniej wyznaczającej zasadniczą tendencję kapitalistycznego rozwoju. Z drugiej zaś, przez dynamikę konfliktu społecznego (ostatecznie o klasowych korzeniach) w danym miejscu i czasie, nie tylko w bezpośrednio ekonomicznym wymiarze, ale także politycznym i ideologicznym. Tona tym tle pojawiają się tendencje i kontrtendencje ku określonym wyborom dotyczącym większej jednolitości bądź zróżnicowania różnych hierarchii władzy w kapitalizmie, mającym gwarantować jego najskuteczniejszą reprodukcję. Brak dowolności przejawia się także w zasadniczo państwowych ramach tych poszukiwań. Toznaczy niezależnie od tego, że możemy skonstruować model teoretyczny najskuteczniejszego kapitalizmu pozbawionego rzeszy rywalizujących państw, z globalną klasą kapitalistyczną i państwem światowym, jest to tylko teoretyczna figura bez znaczenia. Kapitalizm nie tylko narodziłsię w systemie państw, ale - jak wspominaliśmy, z powodu nierównomierności i złożoności jego rozwoju oraz ideologicznego znaczenia nacjonalizmu - ich istnienie reprodukował i wciąż reprodukuje, jednocześnie nadając im specyficzny kształt państw kapitalistycznych. Niezależnie od różnorodności reżimów politycznych 


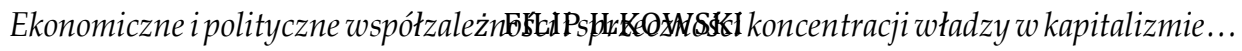

${ }^{25}$ A. Gramsci, Zeszyty filozoficzne, Warszawa 1991, s. 433-447. 
w nich występujących, każde z nich ma za zadanie zapewnienie możliwie najskuteczniejszej akumulacji kapitału we własnych granicach, co jest ostateczną miarą skuteczności wszystkich państw kapitalistycznych. To wszystko niezależnie od powstania prawdziwie globalnej sieci ekonomicznej współzależności, gospodarczego kapitalizmu światowego, coraz potężniejszych jednostek kapitału o zasięgu światowym, jak i wciąż istniejącym tendencjom ku blokom gospodarczo-politycznym, czego najdalej idącym wyrazem jest Unia Europejska. Jednocześnie jest ona przykładem tego, jak trudna i nacechowana sprzecznościami jest integracja wykraczająca poza wymiar bezpośrednio ekonomiczny i jak bardzo państwa narodowe są wciąż głównymi organizmami określającymi terytorialne ramy konkretnej ideologii, konfliktów politycznych, czy kryzysów społecznych.

Dodajmy, że w kontekście tych wyborów, nie ma żadnego wszechwiedzącego narratora, Wielkiego Demiurga klasy panującej (czyli w kapitalizmie po Marksowsku „burżuazji”, a mówiąc inaczej i bez zbędnego bagażu obciążeń: klasy właścicieli kapitału korzystających na związanych z tą własnością relacjach władzy), który ustawia wszystkie elementy w zgodzie z własnymi interesami w danym miejscu i czasie. Ciągły konflikt i rodzaj przetargu istnieje nie tylko między klasami społecznymi, w oparciu o obiektywnie istniejący wyzysk, ale i wewnątrz nich w odniesieniu do różnic dotyczących tego, jak najskuteczniej zorganizować politycznie dane społeczeństwo kapitalistyczne $w$ konkretnym momencie historycznym. Michael Hardt i Antonio Negri uznali, że pojęcie klasy robotniczej/pracowniczej należy zastąpić pojęciem rzeszy, wielości, wywodzącym się od spinozjańskiego multitudo ${ }^{26}$. Zabieg ten wydaje się jednoznacznie błędny, gdyż zaciemnia zrozumienie tego, jak działała kapitalizm i na czym polega wyzysk $\mathrm{w}$ tym systemie. Jednak uznać można, że wpewnym sensie wszystkie klasy społeczne są rzeszą, składając się ostatecznie z poszukujących rozumienia własnej kondycji jednostek. W tym kontekście zdania, że coś jest „Zdaniem burżuazji”, „według klasy średniej”, albo coś „pracownicy uważaja”", są w najlepszym razie uproszczeniem, a często propagandowym nadużyciem, gdyż żadna klasa nie jest blokiem jednakowo myślących ludzi. Oczywiście dotyczy to zresztą także wcześniejszych społeczeństw klasowych, bo tak rozumianą wielością byli także niewolnicy i ich właściciele, czy szlachta i chłopi pańszczyźniani. Jednak kapitalizm, z racji swej sprzecznej dynamiki (rozwoju i kryzysu)

26 A. Negri, Subversive Spinoza. (Un)contemporaryvariations, Manchester-New York 2004, s. 47-49; M.Hardt, A. Negri, Multitude. Warand Democracy in the Age of Empire, New York 2004, s. xiv. 
oraz formalnej obietnicy merytokracji, w spotęgowany sposób zmusza jednostki w ramach wszystkich klas do stałego zmagania się z poszukiwaniami pożądanej kondycji społecznej. Nie zmienia to faktu, że rozmaite jednostki mają w oczywisty sposób różną pozycję w klasowej strukturze społeczeństwa - niezależnie od własnych wyobrażeń na ten temat. Dotyczy to głównie miejsca w relacjach wyzysku, na osi pracy najemnej i kapitału, ale także usadowienia wewnątrz określonych klas społecznych.

Nie zmienia to także faktu, że istnieją konkretne wybory dotyczące modelu integracji ekonomiczno-politycznej, ku którym skłania się klasa panująca - czyli istotna część jej „rzeszy” - w ramach historycznie określonych okoliczności. Każdy taki wybór podejmowany jest w oparciu o przekonanie co do najskuteczniejszej akumulacji kapitału w odniesieniu zarówno do danego państwa kapitalistycznego, jak i poszczególnych właścicieli kapitału. Co istotne, ci właściciele mogą też grupować się w poszczególne, najczęściej nieformalne, frakcje, starając się wpływać na kierunek zmian dający nadzieję na realizacjęich grupowych interesów. W tym kontekście pojęciem, które warto przywołać, jest ukuty przez Gramsciego „blok historyczny” - w oryginale wskazujący na specyficzny sojusz przemysłowców z rozwijającego się dynamicznie kapitalizmu północy Włoch z „blokiem politycznym” zróżnicowanego południowego chłopstwa - wyposażony zarówno we własne interesy na bazie ekonomicznej, jak i własnych intelektualistów nadającym temu blokowi hegemonię ideologiczną w państwie ${ }^{27}$. Co istotne, choć charakter obu tych bloków ostatecznie determinowany jest przez dążenia panującej klasy kapitalistycznej do utrzymania i umocnienia własnego panowania, ze skierowaną w przyszłość wizją skuteczności własnego rozwoju (czyli perspektyw akumulacji kapitału), moją one charakter nie tylko horyzontalny, ale i wertykalny (przynajmniej w odniesieniu do włączenia we własną wizję ideologiczną istotnej części klasy średniej). Można w tym momencie wskazać, że konstrukcje „bloków historycznych” mogą mieć charakter faktycznie „historyczny” - czyli wyrażający długofalową strategię integracji społecznej w oparciu o ideologiczne przekonanie dotyczące wspólnego gruntu interesów ekonomicznych wykraczające poza wąską elitę faktycznych decydentów gospodarczo-politycznych. Współczesnym tego polskim przykładem mogłaby być wizja integracji z instytucjami świata zachodniego, w szczególności Unią Europejską i Paktem Północnoatlantyckim. „Bloki” mogą mieć jednak także bardziej doraźny charakter.

27 P.Sotiris, Gramsci and the Challenges for the Left: The Historical Bloc as a Strategic Concept, «Science \& Society» 2018, vol. 82, nr 1, s. 94-119. 
Znów odwołując się do współczesnego, polskiego przykładu ze zmianą takiego bloku, rodzaju ideologicznego przesunięcia opartego o inne części klas wyższych i średnich, mieliśmy do czynienia w momencie odsunięcia od władzy koalicji P0-PSL na rzecz PiS. Hegemonia nacechowana wizją transformacji po 1989 r. jako sukcesu, oparta o tę część „rzeszy” klasy panującej (z zawsze istniejącym „skapywaniem w dół” ideologii do klasy średniej i pracowniczej), która była zadowolona z własnej sytuacji i perspektyw jej poprawy, zderzyła się - z trwającą walką o ideologiczny „rząd dusz" - z wizją zasadniczo zakorzenioną w niezadowolonej części klas średnich, wspieraną przez część klasy panującej, we własnym mniemaniu wcześniej marginalizowaną. W skrócie: wizja „radosnych i zadowolonych Europejczyków” starła się z wizją „odzyskujących godność i państwo Polaków”. Przy czym obie zakorzenione były w innym układzie „bloku politycznego" z własnym postrzeganiem diagnozy i kuracji w odniesieniu do wspólnego mianownika w postaci rozwoju polskiego kapitalizmu.

Historycznie rzecz ujmując mamy znacznie bardziej dramatyczne przykłady zmian w tym względzie, także w odniesieniu do głębszych „bloków historycznych”. Znów krańcowym przykładem są Niemcy przechodzące do okresu narodowosocjalistycznego. Podzielona klasa panująca w okresie Republiki Weimarskiej, ze skrzydłem od początku wrogim tej postaci politycznej Niemiec, w kontekście głębokiego kryzysu początku lat trzydziestych $\mathrm{w}$ większości postawiła na istotną zmianę reżimu politycznego (jak i, w pewnym stopniu, gospodarczego) ${ }^{28}$. Przykład ten skłania do szerszej refleksji na temat warunków ekonomicznych i politycznych wyboru określonego modelu koncentracji władzy w państwach kapitalistycznych, wyrażonych w tym tekście przez biegunowe „modele” Wood i Bucharina. Wydaje się, że warunkiem zwrotu w kierunku pełnej integracji ekonomiczno-politycznej, zawężającej także skalę akceptowanego przekazu ideologicznego, czyli bucharinowskiego modelu „trustu państwowokapitalistycznego", jest konieczność przezwyciężenia głębokiego kryzysu. Nie odnosi się to koniecznie do kryzysu gospodarczego, ale do kryzysu społecznego (który oczywiście może zaistnieć na bazie gospodarczego), wyrażającego sięw podważaniu istniejącego porządku (politycznego, gospodarczego, a w związku z tym nieuchronnie także panującej ideologii) przez znaczną część społeczeństwa. Na tyle znaczną, że nadającą poczucie konieczności zmian wśród wszystkich klas społecznych (oczywiście zmian niekoniecznie upatrywanych w tych samych roz-

28 J.J. Spielvogel, D. Redles. Hitler and Nazi Germany: A History, London-New York2016, s. $12-26$. 
wiązaniach). Taki był właśnie krańcowy przykład niemiecki. Podkreślmy jednak, że sam kierunek byłw czasach kryzysu lat trzydziestych bardziej uniwersalny - zwrot ku integracji gospodarczej państwa i kapitału, któremu towarzyszyło często zawężanie przestrzeni politycznej niezależnej od bezpośredniej kontroli państwa.

Rodzaj kryzysowej sytuacji nadzwyczajnej prowadzący do przejścia w stronę „trustu państwowokapitalistycznego” mógł wynikać też z krańcowości rywalizacji między państwami - nie zapomnijmy, że Bucharin ukułto pojęcie mając przed oczami I wojnęświatową. Podążając za jego intuicjami można stwierdzić, że specyfika państwa kapitalistycznego wyraża się także w jego umiejscowieniu w ramach gospodarki światowej. W systemie mnogości państw w tych ramach rywalizują one na różne sposoby, a ostateczną miarą skuteczności każdego jest „wzrost gospodarczy”, czyli poziom akumulacji kapitału we własnych granicach w porównaniu z konkurentami. Państwo jest jednak czymś więcej niż organizmem gospodarczym, a do osiągnięcia tego celu mobilizuje wszelkie dostępne instrumenty, które panującym wydają się skuteczne - włącznie z kluczowym instrumentem, jakim jest siła zbrojna. Imperializm jest więc nieodłączny od istnienia systemu rywalizujących państw kapitalistycznych. W momencie wyniszczającej walki gospodarki wojenne stają się spełnieniem wizji pełnej integracji polityczno-gospodarczo-ideologicznej na poziomie państwa mobilizującego wszystkie zasoby w celu pokonania (nierzadko - unicestwienia) innych państw. Korzenie kryzysowe i wojenne tej integracji nie muszą być zresztą rozbieżne, o czym znów świadczy przykład tendencji w kluczowych państwach kapitalistycznych lat 1929-1945. Jeśli uznamy, że zarówno kryzys, jak i imperializm, podobnie jak oligarchizacja gospodarki, są immanentnie związane z dialektyką rozwoju kapitalistycznego, zwrot w kierunku kapitalizmu państwowego wydaje się „wiecznie powracającą” opcją koncentracji władzy.

Należy jednak zauważyć, że historycznie gospodarki przypominające „wojenne” istniały także poza wojną i powrócić do paradoksu stalinowskiej Rosji - czy bardziej generalnie państw nazywających się socjalistycznymi, a nazwanych dziś komunistycznymi, gdzie przez dekady mieliśmy do czynienia z daleko idącą integracją władzy ekonomicznej i politycznej. Oczywiście, mniej lub bardziej adekwatnych teorii dotyczących charakteru tych reżimów nie brakuje. Z naszego punktu widzenia kluczowa wydaje się próba zrozumienia ich miejsca w tendencjach dotyczących kapitalizmu globalnego i na tym tle wskazania na podobieństwa, czy wręcz tożsamość, w odniesieniu do korzeni dialektyki ich rozwoju w porównaniu do innych państw. Jacek Kuroń i Karol Modzelewski mieli 
rację wskazując w swoim znanym Liście Otwartym do Partii z 1965 r., że gospodarka Polski Ludowej opiera się na tej samej zasadzie, którą Marks przypisywał kapitalizmowi - opartej na wyzysku pracowników „produkcji dla produkcji" jako celowi klasy rządzącej29. Rywalizacja w ramach kapitalizmu światowego mierzona „wzrostem gospodarczym”, przy silnym komponencie militarnym, była motywem przewodnim dynamizującym kraje „demokracji ludowej”. Wydaje się, że praktyczna weryfikacja w ujęciu historycznym zarówno państw, które dokonały zmiany reżimu politycznego w latach 1989-1991 (z ZSRR na czele), jak i trwających w tych samych ramach polityczno-ideologicznych (z Chinami na czele), pozwala uznać, że broni się teoria określająca je mianem biurokratycznego kapitalizmu państwowego, sformułowana przez żydowsko-palestyńsko-brytyjskiego marksistę Tony'ego Cliffa w 1949 r. ${ }^{30}$ Przez długi czas stanowiły one swoiste „trusty państwowokapitalistyczne”, próbując następnie głównie od lat siedemdziesiątych XX wieku - utrzymać tempo wzrostu poprzez reformy gospodarcze idące równolegle w stosunku do trendów istniejących w ramach całego kapitalizmu światowego (otwarcie na kapitał międzynarodowy, liberalizacja gospodarki itp.). Dodajmy przy tym, że także model akumulacji kapitału w oparciu o państwo wykraczał poza „blok komunistyczny”, wydając się atrakcyjną drogą rozwoju choćby klasom rządzącym w państwach postkolonialnych. I w momencie wytracania tempa wzrostu państwa te także dokonywały późniejszej rekonstrukcji relacji państwa i kapitału w zgodzie ze zmieniającymi się globalnie trendami ideologicznymi ${ }^{31}$.

Kapitalizmy państwowe bloku wschodniego doskonale obrazująjednak także koszty pełnej integracji gospodarczo-polityczno-ideologicznej, gdy każdy konflikt społeczny pojawiający się na polu jednego z elementów tej triady, bezpośrednio oddziałuje na wszystkie inne. Formalna niezależność władzy politycznej od ekonomicznej pozwala w tym względzie na swego rodzaju decentralizację i rozproszenie odpowiedzialności - przynajmniej

${ }^{29}$ J. Kuroń, K. Modzelewski, List Otwarty do Partii, [w:] J. Kuroń, Dojrzewanie. Pisma polityczne 1964-1968, Warszawa 2009, s. 6-89.

${ }^{30}$ T. Cliff, Państwowy kapitalizm w Rosji, Warszawa 1991.

31 Ciekawym przykładem w tym względzie jest Egipt, który od początku lat pięćdziesiątych przez dwie dekady podążał państwowokapitalistyczną ścieżką rozwoju (pod hasłem „socjalizmu arabskiego”), by w połowie lat siedemdziesiątych być jednym z pierwszych państw dokonujących zwrotu w kierunku prywatyzacji i zmniejszania państwowych subsydiów (zgodnie z ideologią zwaną później neoliberalizmem). Nasuwająca się przykra konstatacja jest taka, że żadna z tych dróg rozwoju kapitalistycznego nie zmieniła na trwałe gospodarczej pozycji tego państwa. 
do pewnego stopnia. Dodajmy do tego atrakcyjnośćideologiczną pluralnej alternacji władzy politycznej w demokracji parlamentarnej, mogącej być polem przetargu między rozmaitymi „blokami politycznymi”, ale przede wszystkim postrzeganej jako urzeczywistnienie obietnicy ludowładztwa. Oczywiście parlamentaryzm nie musi automatycznie towarzyszyć formalnej niezależności władzy ekonomicznej i politycznej, ale faktem jest, że we współczesnym realnym kapitalizmie wciąż stanowi dominującą postać reżimu politycznego wśród wiodących państw świata. Teformy reżimów gospodarczych i politycznych także niosą ze sobą koszty. W pierwszym przypadku związane głównie z ograniczoną kontrolą poczynań coraz potężniejszych kapitałów indywidualnych przez państwa. W drugim, z koniecznością gwarancji znaczne szerszej przestrzeni wolności słowa i organizowania się, także, $w$ pewnej mierze, $w$ odniesieniu do poglądów i ugrupowań uznawanych za wrogie istniejącemu porządkowi. Jednak w czasach względnego „pokoju społecznego” - choć jest to istotne „jednak" - korzyści ze stabilizacji tego porządku rekompensują koszty $\mathrm{z}$ nadmiarem.

Jednocześnie model "trustu państwowokapitalistycznego" staje się ciasnym gorsetem w kontekście koncentracji i centralizacji kapitału nie w skali państwowej, ale globalnej. Formalna niezależność indywidualnych kapitałów od państwa pozwala im na większą „elastyczność” - by użyć tego mocno ideologicznie eksploatowanego terminu - przy jednoczesnym przedstawianiu własnej ekspansji jako pozbawionego znaczenia politycznego uczestnictwa w „,wolnej”, „normalnej” globalnej grze rynkowej. To, co Wood nazywała „ekspansją bez podboju”, byłoby dużo trudniejsze bez tej niezależności. Jednak wydaje się, że myliła się ona opisując współczesny imperializm jako piramidę państw ze Stanami Zjednoczonymi na czele, pilnującymi nieskrępowanego działania kapitału w skali globalnej32. Oddzielenie momentu ekonomicznego i politycznego w kapitalizmie nigdy nie jest pełne. $W$ tym sensie, że konkurencji coraz potężniejszych molochów kapitałowych na rynku światowym wciąż towarzyszy konkurencja państw kapitalistycznych o jak najskuteczniejsząakumulację kapitału we własnych granicach - co wiąże się także $\mathrm{z}$ dbaniem o „własne” molochy, nawet jeśli rzadko są one formalną własnością państwowa. Dostrzegalny zwrot ku "narodowemu kapitalizmowi” w kontekście stagnacji gospodarczej ostatniej dekady, czy chęć utrzymania hegemonicznej pozycji w kapitalizmie światowym przez Stany Zjednoczone poprzez wywoływanie „wojen handlowych” z konkurentami w czasach

${ }^{32}$ E.M. Wood, Empire of Capital..., s. 137-159. 
administracji Donalda Trumpa jest widocznym sygnałem, że globalizacja gospodarki nie przynosi ani stępienia rywalizacji międzypaństwowej, ani (używając określenia Chrisa Harmana) strukturalnej współzależności państwa i kapitału33, nawet jeśli nie przybiera ona postaci „trustu państwowokapitalistycznego".

Znów podkreślmy, że nie oznacza to ostatecznego zamknięcia drogi państwowokapitalistycznej w bardziej tradycyjnej postaci. Kapitalizm okazał się bardzo plastyczny w swych politycznych ucieleśnieniach, więc nauczył ostrożności co do diagnozowana ich przyszłych form. Nie oznacza też, parafrazując najbardziej znaną polską rewolucjonistkę Różę Luksemburg, że postacie modeli politycznych i gospodarczych rozwoju kapitalistycznego są „, różnymi metodami postępu historycznego, które można wybrać według gustu w bufecie historii, jak gorące lub zimne parówki"34. Przesunięcia i zwroty w odniesieniu do postaci koncentracji władzy w kapitalizmie warunkowane są zarówno dialektyką rozwoju kapitalistycznego, jak i konkretnymi momentami w tym rozwoju historycznym wyznaczanymi skaląkonfliktów społecznych, zarówno między klasami, jak i wewnątrz nich. Współzależności i sprzeczności na tym polu niezmiennie tworzyć będą historię polityczną okresu kapitalizmu w dziejach ludzkości.

\section{Bibliografia}

F. Alvaredo, L. Chancel, T.Piketty, E. Saez, G. Zucman, World Inequality Report 2018. Executive Summary, https://wir2018.wid.world/executive-summary.html (31.05.2019).

K. Amadeo, US GDP by Year Compared to Recessions and Events, "the balance", https://www. thebalance.com/us-gdp-by-year-3305543 (29.05.2019).

B. Anderson, Wspólnoty wyobrażone: rozważania o źródłach i rozprzestrzenianiu się nacjonalizmu, Kraków 1997.

N. Bucharin, Imperializm i gospodarka światowa, Warszawa 1934.

A. Callinicos, Imperialism and Global Political Economy, Cambridge, Malden 2009.

T. Cliff, Państwowy kapitalizm w Rosji, Warszawa 1991.

F. Engels, Anty-During. Przewrót w nauce dokonany przez pana Eugeniusza Duringa, [w:] K. Marks, F. Engels, Dzieła, t. 20, Warszawa 1972.

F. Engels, Pochodzenie rodziny, własności prywatnej i państwa, [w:] K. Marks, F. Engels, Dzieła, t. 21, Warszawa 1969.

E. Gellner, Narody i nacjonalizm, Warszawa 2009.

A. Gramsci, Zeszyty filozoficzne, Warszawa 1991.

33 Ch. Harman, Kapitalizm zombi. Globalny kryzys i aktualność myśli Marksa, Warszawa 2011, s. 159.

${ }^{34}$ R. Luksemburg, Reforma socjalna czy rewolucja?, R. Luksemburg, Kryzys socjaldemokracji, Warszawa 2005, s. 94. 
M. Hardt, A. Negri, Multitude. War and Democracy in the Age of Empire, New York 2004.

C. Harman, Kapitalizm zombi. Globalny kryzys i aktualność myśli Marksa, Warszawa 2011.

R. Hilferding, Kapitat finansowy: studium o najnowszym rozwoju kapitalizmu, Warszawa 1958.

F.Ilkowski, Dialektyka imperializmu kapitalistycznego, «Studia Politologiczne» 2016, vol. 41.

F. Ilkowski, Teorie klasyczne imperializmu kapitalistycznego. Zarys krytyczny, Toruń 2015.

J. Kuroń, K. Modzelewski, List Otwarty do Partii, [w:] J. Kuroń, Dojrzewanie. Pisma polityczne 1964-1968, Warszawa 2009.

R. Luksemburg, Reforma socjalna czy rewolucja?, R. Luksemburg, Kryzys socjaldemokracji, Warszawa 2005.

K. Marks, Kapitał, t. 1, Warszawa 1951.

A. Negri, Subversive Spinoza. (Un)contemporary variations, Manchester-New York 2004.

T. Piketty, G. Zucman, PIKETTY-ZUCMAN WEALTH-INCOME DATA SET, Table US.2: National income and private weal th in the U.S., 1770-2010 (annual series), piketty. pse.ens.fr/files/capitalisback/USA.xlsx (31.05.2019).

S. Sledge, Dynamic competition: a look at firms in the Fortune Global 500, "Competitiveness Review» 2011, nr 21(5), s. 428-440, doi:10.1108/10595421111171939 (30.05.2019).

P.Sotiris, Gramsciand the Challenges for the Left: The Historical Bloc as a Strategic Concept, «Science \& Society» 2018, vol. 82, nr 1.

J.J. Spielvogel, D. Redles, Hitler and Nazi Germany: A History, London-New York 2016.

L. Trocki, Historia rewolucji rosyjskiej, t. 1, Rewolucja lutowa, Warszawa 1932, https://www. marxists.org/polski/trocki/1930/hrr/index.htm (15.06.2019).

I. Wallerstein, Analiza systemów-światów. Wprowadzenie, Warszawa 2007.

M. Weber, Polityka jako zawód i powołanie [w:] Polityka jako zawód i powołanie, Kraków-Warszawa 1998.

E.M. Wood, Empire of Capital, London-New York 2005. 